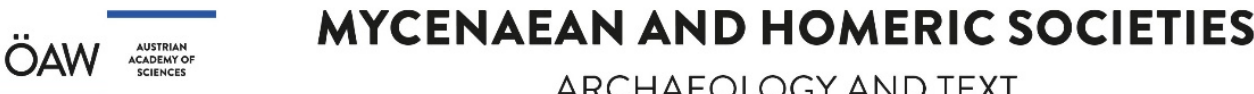 \\ ARCHAEOLOGY AND TEXT
}

Collected Papers of

\section{SIGRID DEGER-JALKOTZY}

edited by Birgitta Eder and Ulrike Schuh

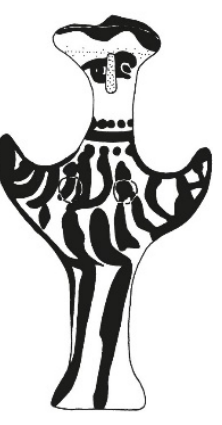

37.

S. Deger-Jalkotzy

\section{The Last Mycenaeans and their Successors Updated}

in: S. Gitin - A. Mazar - E. Stern (eds.), Mediterranean Peoples in Transition. Thirteenth to Early Tenth Centuries BCE. In Honor of Professor Trude Dothan (Jerusalem 1998) 114-128

(C) Israel Exploration Society

mit freundlicher Genehmigung / with kind permission

Dieses Dokument darf ausschließlich für wissenschaftliche Zwecke genutzt werden (Lizenz CC BY-NC-ND), gewerbliche Nutzung wird urheberrechtlich verfolgt. 


\section{MEDITERRANEAN PEOPLES IN TRANSITION}

Thirteenth to Early Tenth Centuries BCE

Editors

Seymour Gitin, Amihai Mazar and Ephraim Stern

In Honor of Professor Trude Dothan

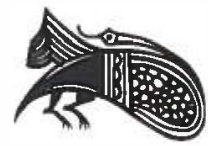

Mykenische Kommission
der osterreichischen Akademle
der Wissenschaften
A-1010 Wien, Dr. Ignaz Selpel-Platz 2

Mnv. Nr.749 
This volume was made possible by generous contributions from the Philip and Muriel Berman Foundation and the Dorot Foundation.

Editors: Seymour Gitin, Amihai Mazar and Ephraim Stern Executive editor: JosEPH AvIRAM

Production editor: Alan PARIS

(C) 1998 by the IsRael Exploration Society

All rights reserved

This book may not be reproduced in whole or part in any form (except by reviewers) without written permission from the publisher

ISBN 965-221-036-6

Printed in Israel by Keterpress Enterprises Ltd., Jerusalem 


\section{TABLE OF CONTENTS}

ix $\quad$ Foreword and Acknowledgments

xi Greetings from Philip and Muriel Berman

xiii A Tribute to Trude Dothan

xvi Bibliography: Books and Articles by Trude Dothan

\section{CHAPTER I: TRADITION AND CHANGE IN THE MEDITERRANEAN BASIN}

Elizabeth B. French

2 The Ups and Downs of Mycenae: 1250-1150 BCE Gerald Cadogan

6 The Thirteenth Century Changes in Cyprus in their East Mediterranean Context WOlF-DieTrich NiEMEIER

17 The Mycenaeans in Western Anatolia and the Problem of the Origins of the Sea Peoples LUCIA VAGNETTI

66 Variety and Function of the Aegean Derivative Pottery in the Central Mediterranean in the Late Bronze Age

\section{CHAPTER II: MECHANISMS OF IDENTITY AND CULTURAL TRANSFORMATION}

PAUl Åström

80 Continuity or Discontinuity: Indigenous and Foreign Elements in Cyprus around 1200 BCE Ora NegBI

87 Reflections on the Ethnicity of Cyprus in the Eleventh Century BCE GUENTER KOPCKE

94 Cypriote Figural Bronzes: Questions about Mycenaean Civilization and Sea People Shlomo Bunimovitz

103 Sea Peoples in Cyprus and Israel: A Comparative Study of Immigration Processes Sigrid DEgER-JALKOTZY

114 The Last Mycenaeans and their Successors Updated Christos G. Doumas

129 Aegeans in the Levant: Myth and Reality 
CHAPTER III: PHILISTIA: CHRONOLOGY AND CULTURAL AFFINITIES

ISRAEL FINKELSTEIN

140 Philistine Chronology: High, Middle or Low?

TRUde Dothan

148 Initial Philistine Settlement: From Migration to Coexistence

Seymour Gitin

162 Philistia in Transition: The Tenth Century BCE and Beyond

184 Discussion

\section{CHAPTER IV: EGYPTIANS, CANAANITES, ISRAELITES, AND AMMONITES}

JAMES M. WeINSTEIN

188 Egyptian Relations with the Eastern Mediterranean World at the End of the Second Millennium BCE

DAvid UssishKIN

197 The Destruction of Megiddo at the End of the Late Bronze Age and its Historical Significance William G. Dever

220 Israelite Origins and the "Nomadic Ideal": Can Archaeology Separate Fact from Fiction? ADAM ZERTAL

238 The Iron Age I Culture in the Hill-Country of Canaan-A Manassite Perspective LARRY G. HERR

251 Tell el-'Umayri and the Madaba Plains Region during the Late Bronze-Iron Age I Transition

265 Discussion

CHAPTER V: ALTERNATIVE PERSPECTIVES FOR UNDERSTANDING THE LATE BRONZE AGE-EARLY IRON AGE TRANSITION

Neil Asher Silberman

268 The Sea Peoples, the Victorians and Us: Modern Social Ideology and Changing Archaeological Interpretations of the Late Bronze Age Collapse

VASSOS KARAGEORGHIS

276 Hearths and Bathtubs in Cyprus: A "Sea Peoples"” Innovation?

DAVID B. SMALL

283 Surviving the Collapse: The Oikos and Structural Continuity between Late Bronze Age and Later Greece

SUSAN SHERRATT

292 "Sea Peoples" and the Economic Structure of the Late Second Millennium in the Eastern Mediterranean

JAMES D. MuHLY

314 Copper, Tin, Silver and Iron: The Search for Metallic Ores as an Incentive for Foreign Expansion 


\section{CHAPTER VI: THE CRYSTALLIZATION OF NEW SOCIETIES}

Maria Iacovou

332 Philistia and Cyprus in the Eleventh Century: From a Similar Prehistory to a Diverse

Protohistory

EPHRAIM STERN

345 The Relations between the Sea Peoples and the Phoenicians in the Twelfth and Eleventh Centuries BCE

Nicolas Coldstream

353 The First Exchanges between Euboeans and Phoenicians: Who Took the Initiative?

361 Discussion

\section{CHAPTER VII: POTTERY AND CULTURE CHANGE: SOME NEW ANALYSES}

\section{Amihai MaZAR}

368 On the Appearance of Red Slip in the Iron Age I Period in Israel

ANN KiLlebrew

379 Ceramic Typology and Technology of Late Bronze II and Iron I Assemblages from Tel MiqneEkron: The Transition from Canaanite to Philistine Culture

ANAT COHEN-WeInBERgER

406 Petrographic Analysis of the Egyptian Forms from Stratum VI at Tel Beth-Shean Ayelet Gilboa

413 Iron Age I-IIA Pottery Evolution at Dor-Regional Contexts and the Cypriot Connection

\section{CHAPTER VIII: COASTAL TRADE, COMMERCE AND SETTLEMENT}

Avner Raban

428 Near Eastern Harbors: Thirteenth-Seventh Centuries BCE Michal ArTZY

439 Routes, Trade, Boats and "Nomads of the Sea"

SAMUEL WolfF

449 An Iron Age I Site at 'En Hagit (Northern Ramat Manashe)

\section{CHAPTER IX: CANAANITES AND ISRAELITES IN THE NORTH OF ISRAEL}

AMNON BEN-TOR

456 The Fall of Canaanite Hazor-The "Who" and "When" Questions Moshe Kochavi

468 The Eleventh Century BCE Tripartite Pillar Building at Tel Hadar Avraham Biran

479 Biblical Dan and the House of David Inscription: From the Late Bronze Age to the Iron Age 


\title{
THE LAST MYCENAEANS AND THEIR SUCCESSORS UPDATED
}

\author{
SIGRID DEGER-JALKOTZY
}

\begin{abstract}
Thirty years after V. Desborough's famous book was published our knowledge of the Late Helladic IIIC period of Greece and of the close of the Mycenaean Age has been greatly enhanced by the results of recent excavations and archaeological research. This paper will deal with cultural and historical developments of the post-palatial Mycenaean period of Greece and the Aegean and with the transition from the Mycenaean to the Early Iron Age of Greece. In particular, the paper will focus on the Late Helladic IIIC Middle phase, which witnessed the last flower of Mycenaean civilization. Its achievements were of great momentum to the cultural, social, and political processes during the period of transition. Chronological questions will concern, inter alia, the 12th and 11th centuries of Cyprus and its relationship to the Aegean, as well as the vexing problem of the term "Submycenaean." Finally, the current discussion of Mycenaean survival in the culture of 1st-millennium Greece will be considered.
\end{abstract}

During the period which we are discussing at this symposium, Greece and the Aegean world experienced a dramatic turning point of history, followed by a process of major cultural transformation. Towards the end of the 13th century BCE the collapse of the Mycenaean palaces brought to a close the first high civilization ("Hochkultur") achieved by the Greeks. The two centuries which followed those catastrophes are subdivided, in terms of Aegean archaeology and chronology, into Late Helladic $(=\mathrm{LH})$ IIIC, Submycenaean (=SubMyc) and Protogeometric (=PG). They received a monographic treatment about 30 years ago by V. Desborough in a book which has prompted the title of this paper (Desborough 1964). This book became a work of reference for at least two generations of scholars, and rightly so. However, during the last 15-20 years a rich harvest of archaeological evidence and material culture study has been gradually calling for a modification of Desborough's vision of the post-palatial era of Mycenaean Greece. In spite of this new evidence, The Last Mycenaeans and their Successors still exercises a great influence, particularly upon specialists working in related disciplines who only occasionally or marginally deal with Aegean prehistory. Despite the synoptical treatises by authors like F. Schachermeyr and J. Vanschoonwinkel, Desborough's book has not really found a suitable successor (Schachermeyr 1980; Vanschoonwinkel 1991).

For this reason, it is perhaps not superfluous to touch upon a few points where recent discoveries have led to a different knowledge and hence to a different evaluation of the postpalatial age of Mycenaean Greece. I would like to dedicate this very brief sketch ${ }^{1}$ to Trude Dothan in fond remembrance of our many discussions since the Symposium of Zwettl, on this favorite subject. I must apologize, however, as the "Sea

1. I apologize for having included many titles of my own in this paper's bibliography. Prompted partly by my own interests and partly by invitations, I have lately dealt with the post-palatial age of Mycenaean Greece and with the transitional period to the Early Iron Age on several occasions. Since I do not want to repeat myself, this paper will at various points refer to my previous publications where certain aspects have already been treated. 


\begin{tabular}{|c|c|c|}
\hline Tiryns & & Mycenae \\
\hline SH III B Mitte & & LH III B 1 (Late) \\
\hline SH III B Spät & & \multirow[t]{2}{*}{ LH III B 2} \\
\hline SH III B Ende & & \\
\hline Übergang SH III B/C & \multirow[t]{3}{*}{ LH III C Early } & LH III C Earliest (Linear) \\
\hline SH III C Früh Phase 1 & & \multirow[t]{2}{*}{ Tower Phase } \\
\hline $\begin{array}{rr}\text { Phase } 2 \\
\text { Phase } \\
\end{array}$ & & \\
\hline SH III C Entwickelt & \multirow[t]{2}{*}{ LH III C Middle } & LH III C Developed \\
\hline SH III C Fortgeschritten 1 & & LH III C Advanced \\
\hline SH III C Fortgeschritten 2 & LH III C Late & LH III C Late \\
\hline SH III C Spät- & Submycenaean & Submycenaean \\
\hline
\end{tabular}

Fig. 1 Late Mycenaean chronology (based on the Argive sequence). Graphics: A. Bächle, I. Schlor after Sherratt 1981 (Mycenae) and Podzuweit 1978; 1979; 1981; 1983; 1988 (Tiryns)

Peoples" for once do not play a prominent part in my considerations!

In the words of V. Desborough, the postpalatial age of Greece was first characterized by a "complex period of decline" which followed what he visualized as the "Mycenaean empire" (Desborough 1964:218-220). Thereafter, "a period of transition and fundamental transformation followed out of which, in the fullness of time, the characteristic features of classical Greece were to emerge" (Desborough 1964: XVII). According to the present state of knowledge, the second description not only applies to the transitional period between the latest Mycenaean phases and the PG era as Desborough saw it, but in fact to the entire period of LH IIIC (Deger-Jalkotzy 1991a). It is therefore the first of Desborough's statements quoted above which most needs to be updated: LH IIIC was more than merely a "complex period of decline"; nor was it merely the first stretch of the "Dark Ages of Greece" (Desborough 1972).

Since Desborough's masterly geographical survey of the Mycenaean Greek regions after the fall of the palaces was written (Desborough 1964: chapter III), the increase of archaeological evidence has not only added much new material to this panorama (see the compilations by Schachermeyr 1980 and Vanschoonwinkel 1991). During the last two decades LH IIIC has, moreover, gained a diachronic dimension and a historical perspective: Stratified pottery deposits of settlement excavations at Mycenae, Tiryns, Lefkandi, together with the long sequence of stratified burial deposits found at the LH IIIC cemetery of Perati have helped to define the successive pottery phases and hence the relative chronology of LH IIIC (Lefkandi: Popham and Milburn 1971; Mycenae: French 1969; Sherratt 1981:chapter 3; Tiryns: Podzuweit 1978; 1979 ; 1981; 1983; 1988; Perati: Iacovidis 196970). The examination of the stratified deposits, as well as of the general material culture of LH IIIC has allowed for a division of this period into an Early, a Middle and a Late phase (this division which seems to have been first developed by Dr. E. French's privately distributed LH IIIC pottery chart was elaborated by Schachermeyr 1980 and Mountjoy 1986). Their subphases display a great deal of regional variation, and the correlation with the basic framework of reference provided by the Argive se- 
quence-admirably displayed this morning by Dr. French-is not always easy. As a matter of fact, there are even divergences between the sequences published for the two principal Argive sites of Mycenae and Tiryns (fig. 1).

It is now clear that A. Furumark's subdivisions of LH IIIC pottery and its relative chronology need much revision. Let me mention for instance the so-called Octopus Style which was characteristic of nesiotic pottery and popular at many coastal sites of the mainland. It did not begin during LH IIIC Early, but in LH IIIC Middle, and was current particularly during $\mathrm{LH}$ IIIC Advanced. The same applies to the mature Close Style of the Argolid (see also Dr. E. French's paper in this volume).

On the other hand, it has become equally clear that any idea of abandoning Furumark's LH IIIC 2 = SubMyc phase and of throwing it together with LH IIIC Late into one and the same chronological horizon (as championed by Rutter 1978) cannot be maintained. It is true that the characteristics of Attic Submycenaean pottery were not universally adopted. This has been demonstrated for various regions of the "Mycenaean periphery" (northwest and central Greece: Schachermeyr 1980:part III; 1983: 250-251; Deger-Jalkotzy 1991d; northern Greece: Wardle 1994; western Peloponnese: Schachermeyr 1980: chapters 12-14; Coulson 1983; 1986; Deger-Jalkotzy 1991b) where local derivatives of LH IIIC Late pottery were preferred. It is, however, important to note that characteristic phenomena of LH IIIC Late pottery-making like the so-called "White Ware" (Popham and Milburn 1971:344) never occur in contexts of Submycenaean date (Schachermeyr 1980:185-188; for definitive decorative features of LH IIIC Late $c f$. Mountjoy 1988:5-18). In other words, they were no longer produced at that time and thus call for a chronological separation of LH IIIC Late from Submycenaean (Schachermeyr 1980:185-188; Mountjoy 1988: 5-18).

Moreover, during Submycenaean some new phenomena appeared which had been alien to LH IIIC Late ${ }^{2}$ such as pairs of long dress pins, arched fibulae, Dark Age handmade pottery
(Reber 1991) and various kinds of single burials. Thus, whatever you call this phase-LH IIIC Final, LH IIIC Late 2, or Submycenaean-its succession to LH IIIC Late and its duration of about two generations or 40 to 50 years (see also Mountjoy 1988) must not be eliminated from the chronological chart. Nor should it be disregarded in discussing the question of synchronisms between Greece and Cyprus during the 11 th century BCE (Deger-Jalkotzy 1994).

I may perhaps further mention that the evidence of the new Greek-Austrian excavations at Elateia in central Greece has again confirmed that iron weapons and dress-fasteners made of iron were introduced after the SubMyc period, either during a transitional phase to, or already in the course of Early Protogeometric (the metal finds from Elateia are being studied by Dr. Phanouria Dakoronia). The same is true of the use of compass and multiple brush for the application of concentric circle patterns on painted vases, as I have argued at the Symposium on the Mycenaean Periphery 1994 at Lamia (to appear in the proceedings; for a different view cf. Jacob-Felsch 1988).

Let us now leave the field of chronology. It has always been maintained that the breakdown of the Mycenaean palace civilization ${ }^{3}$ caused a great deal of upheaval, of population move-

2. This view which conforms to a long-standing communis opinio has been challenged by P.A. Mountjoy (Mountjoy 1988), on grounds of a stylistic re-evaluation of the pottery found in the graves of the Kerameikos Pompeion Cemetery at Athens. Dr. Mountjoy now contends that these burials did not begin in Submycenaean but in LH IIIC Late. She consequently further argues that the new cultural elements which are commonly believed to have appeared in Submycenaean also began, in fact, in LH IIIC Late. It is impossible to discuss this new proposal here. Suffice it to mention that bronze shield rings bearing impressed dots can be dated at Elateia, too, in LH IIIC Late (Greek-Austrian excavations, cf. below). However, Dr. Mountjoy's arguments still await support from indisputable LH IIIC Late parallels as far as the other phenomena are concerned (pairs of dress pins, arched fibulae, handmade pottery etc.)

3. It is not the aim of this paper to discuss again the causes which led to the catastrophes of the Mycenaean palaces and other settlements at the close of LH IIIB2. We have dealt with this subject on various occasions (cf. e.g. Deger-Jalkotzy 199 lc and Deger-Jalkotzy forthcoming). 
ments and of general unrest. This view has been confirmed by recent evidence. Destruction levels mark the history of settlements throughout the LH IIIC period (material compiled by Vanschoonwinkel 1991; for diagrams cf. Deger-Jalkotzy 1994:figs. 2; 3), not all of them attributable to natural catastrophes or to domestic accidents. Some were clearly caused by human action (Kilian 1985:77; 1988:135; Schilardi 1992: 631-634). The unstable conditions of the period are also indicated by many hoard-finds of $\mathrm{LH}$ IIIC date (Spyropoulos 1972). In mainland Greece a prehistoric admixture to the Mycenaean pottery appeared shortly before and in the wake of the great catastrophes. This socalled "Handmade Burnished Ware," which has provoked a never-ending scholarly discussion (for a recent synoptical treatment see Pilidou 1994), was found in Crete in considerably earlier contexts of Chania and Kommos whereas on the mainland it can be dated to LH III B 2 through LH IIIC Early or Developed. This pottery phenomenon is commonly ascribed to a new and foreign population element which turned up in the Aegean towards the close of the 13th century BCE and spread as far as Cyprus where it has been found in LC III A contexts (Pilidou 1994). By LH IIIC Middle this handmade pottery had vanished from most Aegean sites (differently, Reber 1991:9-15). Its producers and users had either adapted themselves to the Mycenaean civilization or else emigrated to other regions like Cyprus and the Levant-or both: I still believe that both Aegean and nonAegean elements contributed to the ethnogenesis of the Sea Peoples (Deger-Jalkotzy 1994; see also further below).

Whether or not the occurrence of Handmade Burnished pottery was related to the causes of the destruction of the Mycenaean settlements and palaces, it certainly is a testimony to population movements during LH IIIC. Population movements-probably of a different kind-are also suggested by the abandonment of Mycenaean sites, by interruption of habitation or by drastic changes of settlement statistics. Cases in point are Messenia, Eastern Boeotia and Thessaly, to name but a few. In Messenia, the depopulation observed for LH III Early and Developed (cf. McDonald and Rapp 1972: pocket map 8-15) has been confirmed by new surveys under way (Archaeological Reports 1991-92:2728; 1992-93:31-34); the distribution chart of Eastern Boeotia in LH IIIC as shown by Hope Simpson and Dickinson (1979:map 5) is still valid; and in Thessaly there have been so far proved but one site for LH IIIC Early and three or four sites for the subsequent phases of $\mathrm{LH}$ IIIC (Vanschoonwinkel 1991:135-140). Until the Protogeometric Age these regions did not recover from this dramatic loss of population.

What happened to these populations? It may be assumed that many people were killed during the violent events which brought to an end the period of the Mycenaean palaces. But the majority seem to have left their homelands for safer places of refuge. In this respect the tales of Greek historical myths not infrequently find their confirmation in the archaeological record (Sakellariou 1990; Schachermeyr 1983). However, some views held by modern scholars again call for a revisal.

I would like to draw your attention to a longstanding communis opinio according to which immediately after the catastrophes at the end of LH III B a wave of Mycenaean refugees came to Cyprus and inaugurated the Hellenization of the island. However, according to the present state of knowledge of LH IIIC pottery, the beginnings of Late Cypriot III A-as e.g. documented at Maa-Palaiokastro Floor II (Karageorghis and Demas 1985)-took place at a time when LH IIIC was already well under way, possibly during the Tower Phase or even at the end of $\mathrm{LH}$ IIIC Early (French and Åström 1980; Podzuweit 1987; Kling 1989). For comparison, our figs. 2 and 3 showing finds from Maa-Palaiokastro are set against figs. 4 and 6 depicting LH IIIC Early pottery from Greece: note the conical kylikes with monochrome interior, the carinated bowl with horizontal handles and linear decoration, as well as the closed shapes with horizontal bands. LH IIIC pottery from Rhodes, too, compares well with this Late Cypriot III A assemblage (fig. 5): but note that both the Rhodian and the Cypriot one-handled conical cups find 

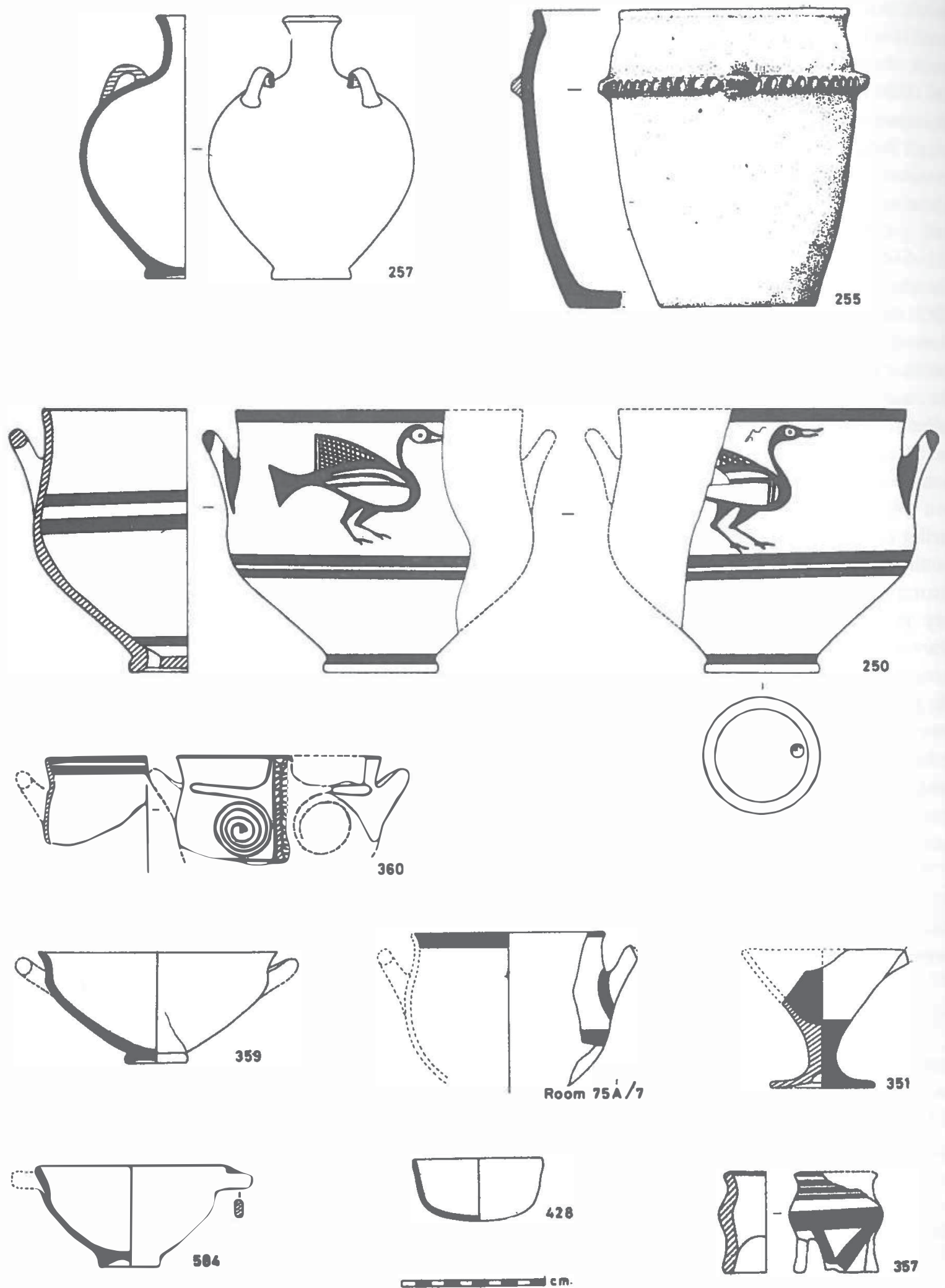

Fig. 2 Maa-Palaiokastro, Floor II: after Karageorghis and Demas 1985: various figs. 

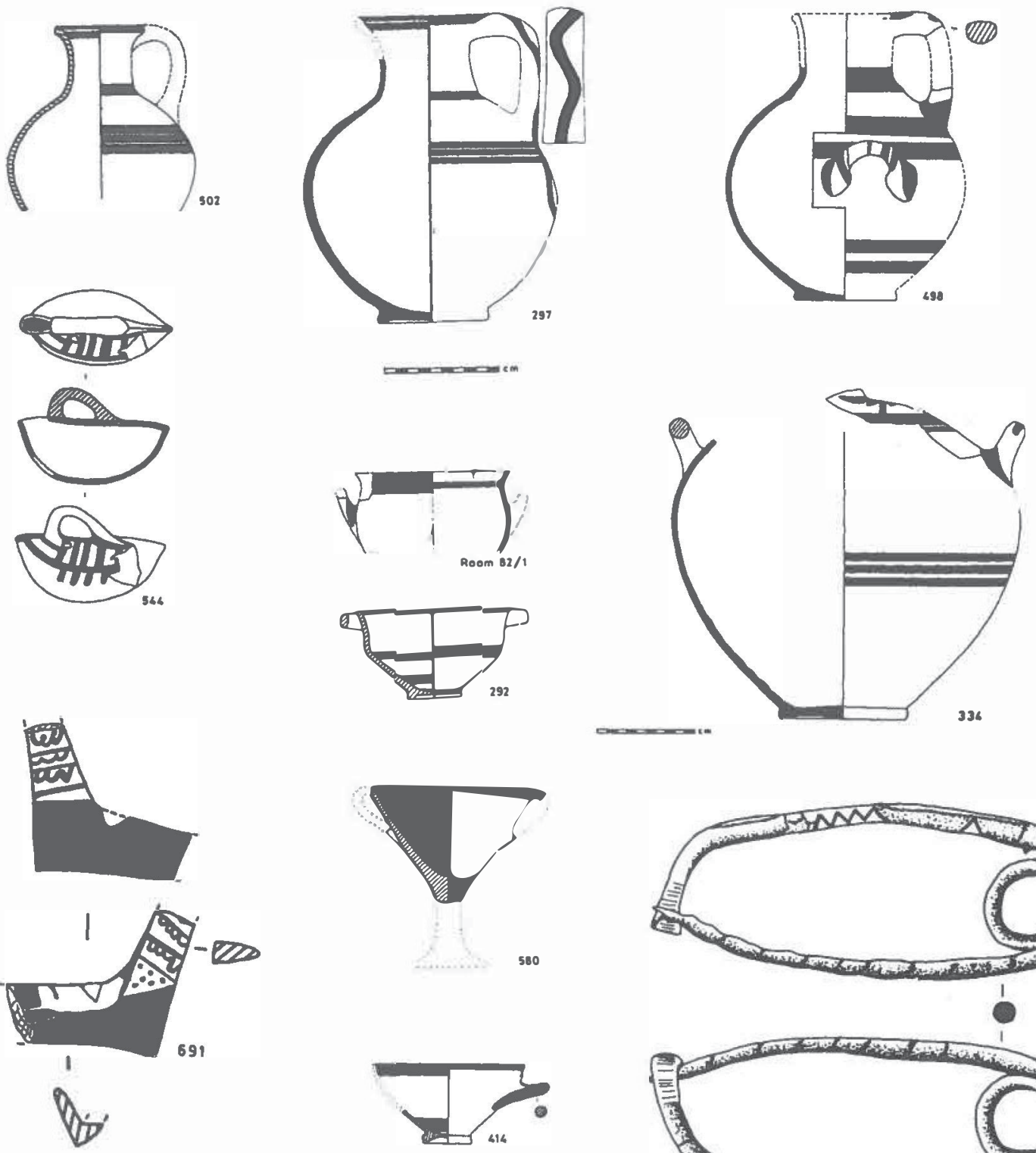

580
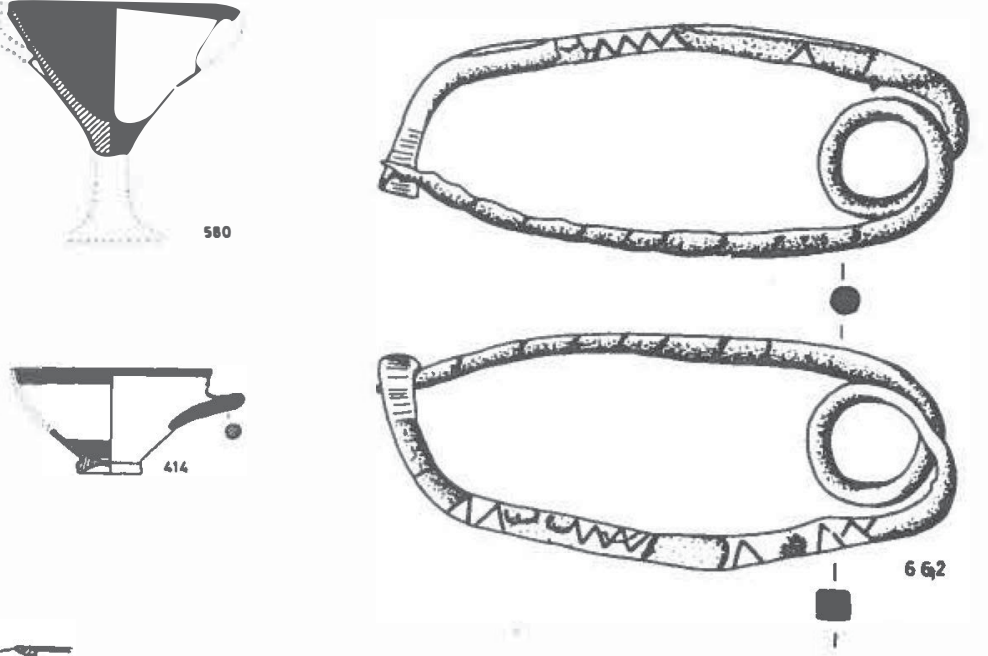

Floor 1
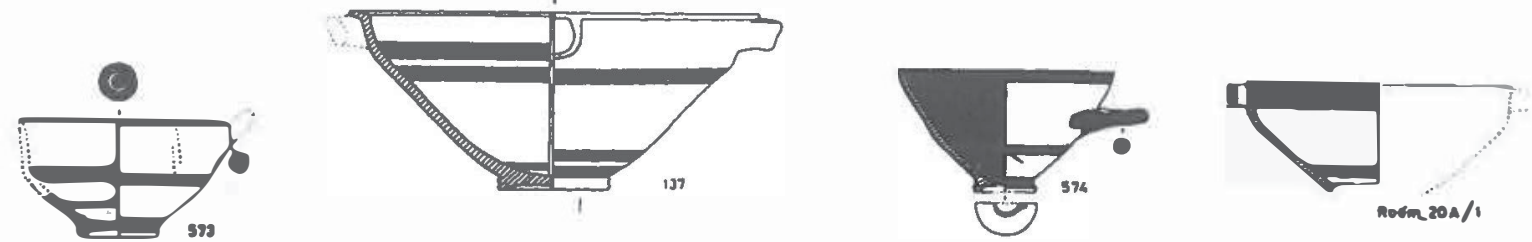

Fig. 3 Maa-Palaiokastro, Floor I: Karageorghis and Demas 1985: plate CCXLIII 

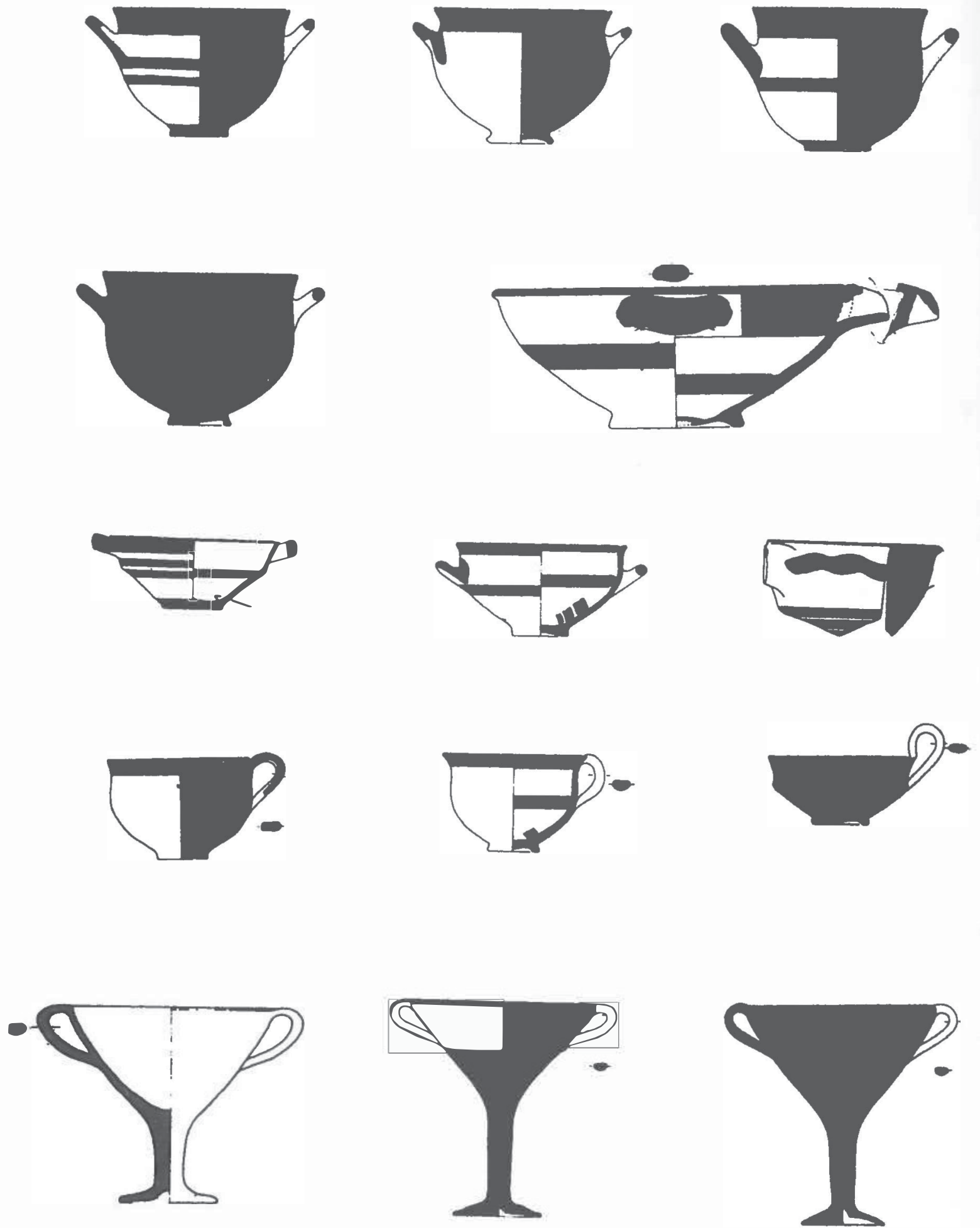

Fig. 4 Pottery types of LH IIIC Early: after Popham and Milburn 1971; Mountjoy 1986; Deger-Jalkotzy 1985 


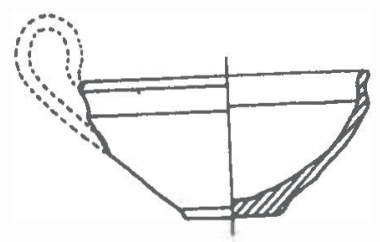

2.T 35/e

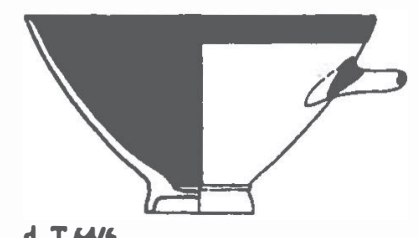

d. $T 64 / 6$

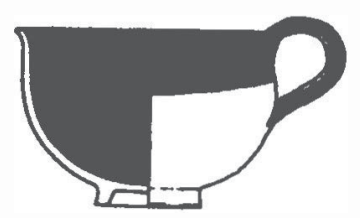

c. Remainos T $467 \%$ a

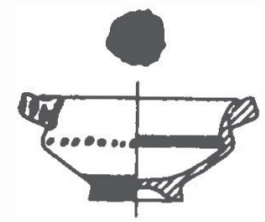

c. T $40 / 10$

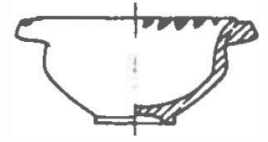

d. T 21/28

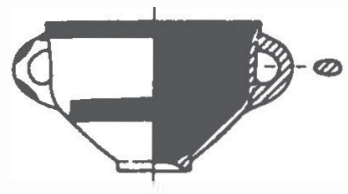

b. T $21 / 15$

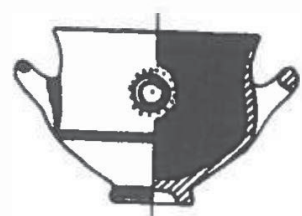

c. $T 72 / 4 b$

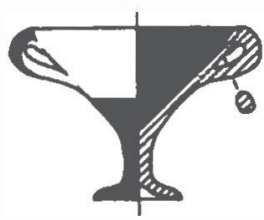

d. T $32 / 36$

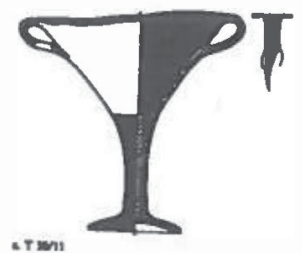

ar

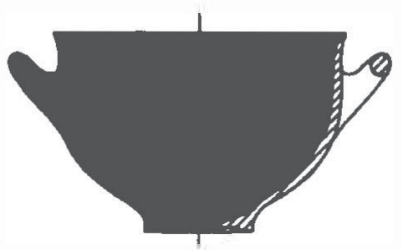

h. T $12 / 8$
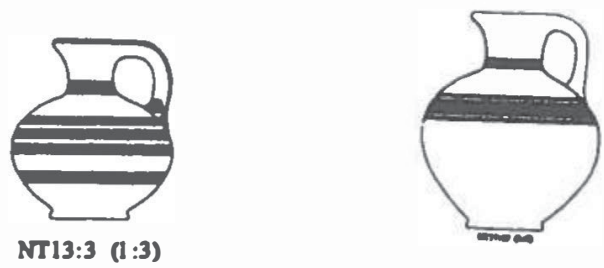

(not to scalo)

Fig. 5 LH IIIC pottery from Rhodes: after Benzi 1992: various figs. 
their parallels in LH IIIC Middle specimens found e.g. at Lefkandi Phase 2a (fig. 7).

Elsewhere I have further argued why I do not believe that the people who arrived in Cyprus during the period of transition from Late Cypriot II C to III A were those who introduced the later Cypriot Greek dialect to the island. They rather were a mixed population of a general Aegean background with a good Minoan admixture (Deger-Jalkotzy 1994, with further references), while the occurrence of Handmade Burnished Ware (see fig. 2) and of violinbowshaped fibulae (fig. 3) suggests that not all newcomers to Cyprus were Mycenaeans or Minoans to the bone (see also further above). I agree with J. Muhly and with the view recently put forward by V. Karageorghis that these newcomers had a lot to do with the ethnogenesis of the ominous "Sea Peoples" (Muhly 1984; Karageorghis 1990).

I therefore would ascribe the great changes which mark the inception of Late Cypriot IIIA to a population movement which already took place within the LH IIIC period. As to those people who fled from their mainland Greek homelands in an easterly direction in the wake of the great catastrophes at the end of LH IIIB (ignoring for now movements to western destinations such as the Ionian islands), it is my opinion that they only reached as far as the Cyclades (Phylakopi, Koukounaries; Keos?) and possibly Rhodes. I hope to be able to elaborate on this particular point on another occasion (for the time being see Deger-Jalkotzy 1991c:147; 1994:16-17).

Particularly under the influence of Desborough's book of 1964, it has become customary to deplore the cultural decline and the deprivation which seem to mark the postpalatial period of LH IIIC. We have already expressed our doubts earlier. If we look at LH IIIC from the height of the palatial civilization of the 14th and 13th centuries BCE, the collapse of the palaces had certainly ushered in a period of decline. The Mycenaeans of LH IIIC were either not able or not willing to uphold the high cultural achievements of the preceding periods.

It was the abandonment of the art of writing which marked the most dramatic cultural loss during LH IIIC. It was an illiterate period and therefore reduced to the standards of a prehistoric society. One is inclined to speak in terms of "barbarization." There is no evidence that the skills and the fine arts of the palatial culture of Mycenaean Greece like monumental architecture, fresco painting, jewellery, seal engraving, and ivory carving were still practiced in $\mathrm{LH}$ IIIC. The production of glass and faience objects seems to have ceased. Objects of fine craftsmanship found in LH IIIC contexts and particularly in tombs of that period may be suspected to have been heirlooms or goods which had been stolen during the turbulences of the time: I would only like to note that to my knowledge no moulds, no LH IIIC tools of an artistcraftsman and no works of fine craftsmanship have so far been found, and that beads and other objects of fine jewellery were mostly found as singletons. Seals, carved bone objects and jewellery of LH IIIC manufacture were simple and unassuming.

Only two crafts were able to ensure the survival of their artistic and technical skill beyond the breakdown of the palatial centers: I am speaking of pottery-making and of bronze-work, particularly the manufacture of arms. They reached a pinnacle of achievement during LH IIIC.

On the other hand, to many population groups of Mycenaean Greece the collapse of the palace system must have also had a lot of positive consequences as soon as the shock caused by the disaster had been overcome. I have dealt with this subject on another occasion and confine myself at this point to a few observations. In the first place, the general population was rescued from suppression and from overload of taxes and of the labor obligations as registered by the Linear B documents. It further appears that the natural environment had been much damaged by relentless exploitation of the soils and by excessive wood-cutting which had been performed in order to meet the demands of the hydrocephalic palace centers. Palaeobotany and pollen analysis have shown that during LH IIIC the grains of the Argolid were larger and of better quality than they had been during the palace 

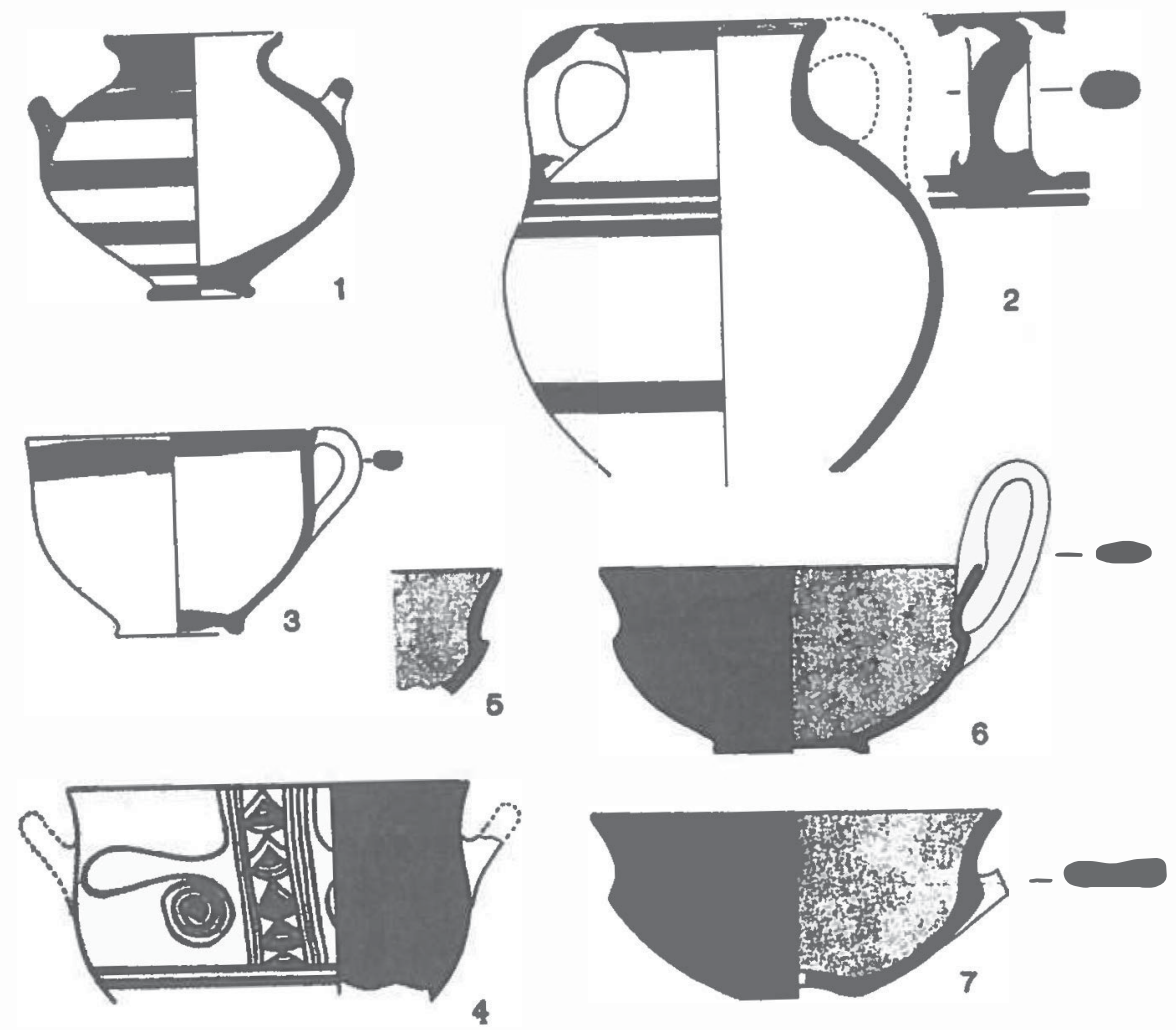

Fig. 6 LH IIIC Early pottery from Lefkandi: Popham and Milburn 1971: fig. 3
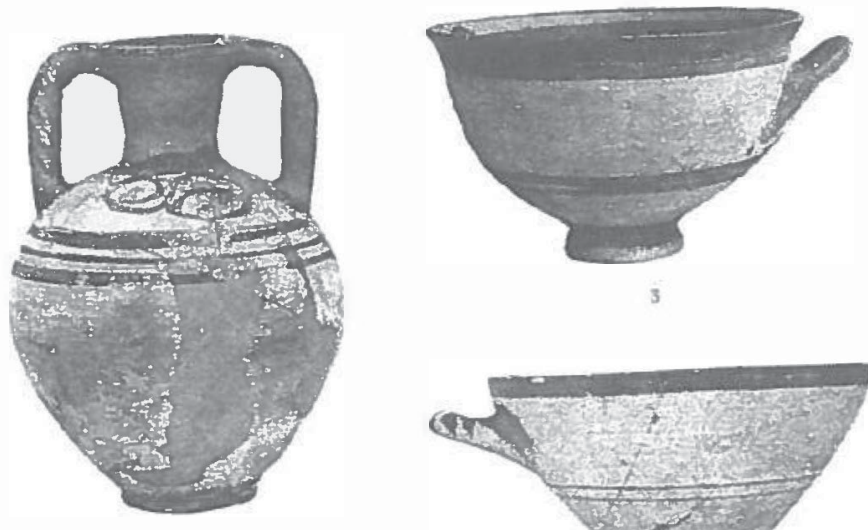

3
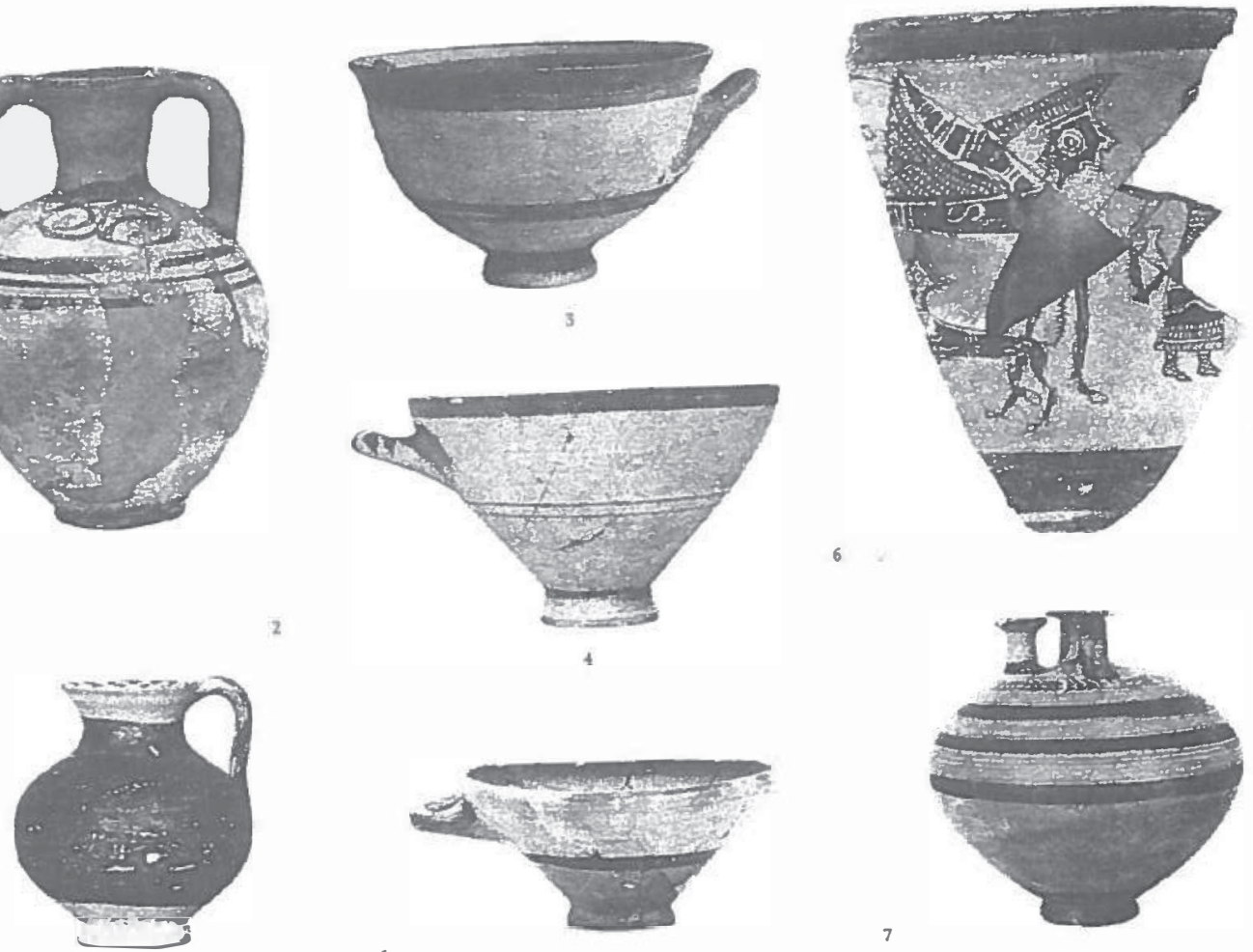

Fig. 7 LH IIIC Middle pottery from Lefkandi: Popham and Milburn 1971: plate 53 
period, while in Messenia the tree population increased as soon as the palace of Pylos had disappeared (for references see Deger-Jalkotzy forthcoming).

Not only the natural environment was redressed to balance. The political interplay of forces, too, had been biased in favor of the palaces, even if there had been no "Mycenaean empire" as Desborough saw it: there is no evidence that the whole Mycenaean territory was ruled by one king whose capital was at Mycenae. Although the Linear B documents seem to betray some cooperation and interactions between the Mycenaean palaces (Killen 1979:176-178), they clearly show that each palace represented an independent state. This is also borne out by the famous inscription of a statue base found in the mortuary chapel of Amenophis III. It refers to four Mycenaean palaces of the Greek mainland, namely Mycenae, Thebes, Pylos (Misana) and probably Tiryns (nupria = Nauplia; for a synoptical treatment of this inscription cf. Lehmann 1989:106-109, with references). But there can be no doubt that the palaces of Mycenaean Greece between themselves monopolized all matters of commerce, of international relations (testified e.g. by the Egyptian inscription just mentioned) and of political predominance. Those regions of Mycenaean Greece which had not transformed their political system to the palace state played a minor role. As I have argued elsewhere, the famous cultural koine of LH III A and B may, on the other hand, also signify that many regions of Mycenaean Greece had no share in the cultural developments but were reduced to cultural provinces in the disparaging meaning of the word, while the palaces set the trends.

After the fall of the palaces, those regions of the Mycenaean periphery were free to develop their own pottery styles and to partake in economic enterprise and foreign relations. For instance, let me refer to the distribution of amber and of bronze objects in LH IIIC which demonstrate that all Mycenaean provinces of that period had free access to the trade of rawmaterials and of finished goods between the eastern and the central Mediterranean (materials collected by Harding 1984; Bouzek 1985).
As for political conditions, the devastations at the close of the 13th century BCE must have led to a deep-rooted change in the realm of social organization and political structure. Neither the palace monarchies nor the supra-regional systems of palatial rule and administration survived. Next to nothing of the ramified Linear B Mycenaean technical and political vocabulary was transmitted to the alphabetic Greek lexicon of the first millennium BCE. Those terms which did survive underwent considerable semantic changes. A case in point is the word damos which in the Linear B texts designated the local community of an administrative district within a Mycenaean palace state. After these kingdoms had collapsed, dämos was transformed into the technical term well known to us: It became the designation of an autonomous Greek polity. In a similar way the word basileus which during the palace period had been used as a technical term for a leader of male personnel levied on a local level was later transformed to become the title of Greek kings.

There are good reasons for assuming that the LH IIIC period had a decisive share in the process of transformation of Greek political institutions and political terms from their Mycenaean origins to their classical appearance. K. Kilian has convincingly shown that right from the beginnings of LH IIIC the settlement patterns and house plans seem to foreshadow the Iron Age and Homeric oikos (Kilian 1985), and the same may well apply to the development of the Greek Polis (Deger-Jalkotzy 1995) and of Greek kingship (Deger-Jalkotzy 1991a; 1991c). It is particularly the evidence of LH IIIC Middle which seems to support this view. This phase of postpalatial Mycenaean Greece witnessed a recreation or even a last blossoming of Mycenaean civilization even if the grand achievements of the past were not regained. The evidence points to the emergence of courtly residences, seats of power at the center of smallscale principalities which could well have qualified for the terms of polis and of damos. Warrior tombs and representations of warriors and of warfare on pictorial vases of this period indicate that military leadership was highly rated, while 
so-called "sceptre-heads" found in LH IIIC contexts (Iacovidis 1970:B 349; Benzi 1992:fig. 183ac) lead us to suspect that the petrified Homeric formula "sceptre-bearing kings" had its roots in the postpalatial Mycenaean period. In short, I do hold the view that LH IIIC was very important to the development of the Greek concept of kingship (Deger-Jalkotzy 1991a).

I do not think that the instance of the Homeric formula was a mere accident. I do not want to talk again of the elaborate pottery styles of LH IIIC Middle (splendidly dealt with by Schachermeyr 1980), nor do I need to repeat the evidence of wide-spread maritime connection to the east and to the west, and of overland trade connections to the North. But I would like to draw your attention to the pictorial vases of the period (Vermeule and Karageorghis 1982: parts XIXIII). The scenes of chariotry and warfare, of hunting and of dancing, of fighting on foot, on chariot and on ships not only seem to reflect an aristocratic lifestyle, nor were they merely images of an ideal self-representation of the $b a$ sileis, the period's social élite. "Heroic scenes" of dramatic action and images of mythical creatures (Deger-Jalkotzy 1994:20-22) seem to suggest that these pictures may have been prompted by heroic epic poetry. Indeed, an Argive LH IIIC Middle vase fragment displays the image of a musician who no longer plays the five- to seven-stringed kithara or the lyra of the palace period. What he holds in his hands is the three-stringed phorminx of the Dark Age epic bard (Slenczka 1974:fig. 9b). It is, to my mind, very likely that epic singers performing at the petty courts of LH IIIC Middle transformed the old legacy of Mycenaean poetry into the oral epic tradition of the early first millennium BCE which was handed down through the centuries until the Homeric Age.

In the field of cult and religion, the shrines and elaborate cult images which had been the prerogative of the Mycenaean palaces slowly developed in the course of LH IIIC to become the public sanctuaries and the images of protective deities of the dämos (Deger-Jalkotzy 1995; for material evidence cf. Hägg and Marinatos eds. 1980).
In short, LH IIIC was not merely a period of decline and of transition. It was also a creative span of time, a period of transformation during which at least some sectors of the Mycenaean heritage were adapted to the vicissitudes of the period and passed down to the first millennium BCE. As we have already stated by way of introduction, Desborough's beautiful characterization of the transitional period from the Bronze Age to the Iron Age in fact ought to be applied to the entire period of LH IIIC. I have called it "Janus-faced" because it displays an entirely Mycenaean character which in LH IIIC Middle even seems to hark back nostalgically to the great past of the palaces (Deger-Jalkotzy 1991c), while at the same time many features of the classical culture of the Hellenes were inaugurated.

However, the transition from LH IIIC to the first millennium BCE was not a linear one. The close of LH IIIC Middle was again accompanied by destructions and in the course of LH IIIC Late and Submycenaean the various regions of Greece met a widely diverging fate. A lot of new evidence relating to the transitional period from Late Mycenaean through Protogeometric was presented at the Symposium on the Mycenaean Periphery held last September at Lamia. Before this evidence has been studied and published, it would be premature to embark on the history of the 11 th and the early 10 th century of Greece.

As to the last Mycenaeans of the Peloponnese, some provinces appear to have suffered a loss of population in the course of or at the close of LH IIIC Late: Achaia was almost depopulated, coastal sites like Lefkandi and Perati were abandoned, and in Laconia there was a settlement hiatus of about 100 years. In my opinion it was during that period that the later Cypriot Greek dialect was brought to the island, on evidence of pottery chronology and of dialect (Deger-Jalkotzy 1994). By contrast, the new evidence of Elateia and of Kalapodi (DegerJalkotzy 1991; Felsch 1987) suggests that in central Greece there was a convergency between Mycenaeans and new population groups out of which a local Protogeometric style emerged. 
The same may well have applied to Thessaly and to the Ionian Islands.

It is therefore obvious that the transition from the Mycenaean Age to the Early Iron Age of Greece was a complex process. Now that we have learned a little more about the 12th century BCE and the "Last Mycenaeans," we will have to concentrate our efforts on "Their Successors" of the 11th and early 10th centuries BCE.

\section{Bibliography}

Benzi, M.

1992 Rodi e la civiltà micenea. Rome.

Bouzek, J.

1985 The Aegean, Anatolia and Europe: Cultural Interrelations in the Second Millennium B.C. SIMA XXIX. Göteborg.

Coulson, W.D.R.

1983 The Dark Age at Nichoria: A Perspective. Pp. 316-329 in Nichoria III. Excavations at Nichoria in Southwest Greece, eds. W.A. McDonald, W.D.E. Coulson and J. Rosser. Minneapolis.

1986 The Dark Age Pottery of Messenia. Göteborg.

Deger-Jalkotzy, S.

1991a Diskontinuität und Kontinuität: Aspekte politischer und sozialer Organisation in mykenischer Zeit und in der Welt der homerischen Epen. Pp. 53-66 in La transizione dal Miceneo all'alto arcaismo. Dal palazzo alla città. Convegno internazionale Roma 1988, eds. D. Musti et al. Roma.

1991b Zum Verlauf der Periode SH III C in Achaia. Pp. 19-29 in Achaia und Elis in der Antike. Symposium Athen 1989, ed. A. Rizakis. Athens.

199lc Die Erforschung des Zusammenbruchs der sogenannten mykenischen Welt und der sogenannten dunklen Jahrhunderte. Pp.127-154 in Zweihundert Jahre HomerForschung: Colloquium Rauricum 2 in Augst bei Basel, ed. J. Latacz. StuttgartLeipzig.

1991d (with Phanouria Dakoronia, Lamia): Elateia (Phokis) und die frühe Geschichte der Griechen: Ein österreichisch-griechisches Grabungsprojekt. Anzeiger der phil.-hist. Klasse der Österreichischen Akademie der Wissenschaften, 127. Jahrgang, 1990:7886.

1994 The Post-palatial Period of Greece: An Aegean Prelude to the 11 th Century
B.C. in Cyprus. Pp. 11-30 in Cyprus in the 11th Century B.C. International Symposium Nicosia 1993, ed. V. Karageorghis. Nicosia.

1995 Mykenische Herrschaftsformen ohne Paläste und die griechische Polis. Pp. $367-$ 377 in Politeia. Society and State in the Aegean Bronze Age. 5th International Aegean Conference Heidelberg 1994, eds. R. Laffineur and W.D. Niemeier. Liège University of Texas at Austin.

forthcoming

On the Negative Aspects of the Mycenaean Palace System. Second International Mycenological Congress at Roma and Napoli 1991.

Desborough, V.R. d'A.

1964 The Last Mycenaeans and Their Successors. Oxford.

1972 The Greek Dark Ages. New York.

Felsch, R.C.S.

1987 Kalapodi. Bericht über die Grabungen im Heiligtum der Artemis Elaphebolos und des Apollon von Hyampolis. Archäologischer Anzeiger, pp. 1-26.

French, E.B.

1969 The First Phase of LH III C. Archäologischer Anzeiger, pp. 133-136.

French, E. B. and Åström, P.

1980 A Colloquium on Late Cypriote III. Reports of the Department of Antiquities of Cyprus, pp. 267-269.

Hägg, R. and Marinatos, N. (eds.)

1981 Sanctuaries and Cults in the Aegean Bronze Age. First International Symposium at the Swedish School at Athens 1980. Stockholm.

Harding, A.F.

1984 The Mycenaeans and Europe. London.

Hope Simpson, R. and Dickinson, O.T.P.K.

1979 A Gazetteer of Aegean Civilisation in the Bronze Age I. Gothenburg. 
Iacovidis, Sp.

1969-70 Perati. To nekrotapheion. Athens.

Jacob-Felsch, M.

1987 Bericht zur spätmykenischen und submykenischen Keramik. Archäologischer Anzeiger, pp. 26-35.

1988 Compass-drawn Concentric Circles in Vase Painting. A Problem of Relative Chronology at the End of the Bronze Age. Pp. 193-199 in Problems in Greek Prehistory: Conference at Manchester 1986, eds. E.B. French and K.A. Wardle. Bristol.

Karageorghis, V.

1990 The End of the Late Bronze Age in Cyprus. Nicosia.

Karageorghis, V. and Demas, M.

1985 Excavations at Kition V. The Pre-Phoenician Levels. Nicosia.

Kilian, K.

1985 La caduta dei palazzi micenei continentali: aspetti archeologici. Pp. 73-115 in Le origini dei Greci: Dori e mondo Egeo, ed. D. Musti. Rome.

1988 Mycenaeans Up To Date, Trends and Changes in Recent Research. Pp. 115152 in Problems in Greek Prehistory: Conference at Manchester 1986, eds. E.B. French and K.A. Wardle. Bristol.

Killen, J.T.

1979 The Knossos Ld (1) Tablets. Pp. 151-181 in Colloquium Mycenaeum. Actes du VIe colloque international sur les textes mycéniens et égéens Chaumont sur Neuchâtel 1975, eds. E. Risch and H. Mühlestein. Neuchâtel/Genève.

1985 The Linear B Tablets and the Mycenaean Economy. Pp. 241-305 in Linear B: $A$ 1984 Survey, eds. A. Morpurgo-Davies and Y. Duhoux. Louvain.

Kling, B.

1989 Local Cypriot Features in the Ceramic of the Late Cypriot III A Period. Pp. 160170 in Early Society in Cyprus, ed. E. Peltenburg. Edinburgh.

Lehmann, G.A.

1991 Die "politisch-historischen" Beziehungen der Ägäis-Welt des 15.-13. Jhs. v.Chr. zu Ägypten und Vorderasien. Pp. 105-126 in Zweihundert Jahre Homer-Forschung: Colloquium Rauricum 2 in Augst bei Basel, ed. J. Latacz. Stuttgart/Leipzig.
McDonald, W.A. and Rapp Jr., G.R. (eds.)

1972 The Minnesota Messenia Expedition. Reconstructing a Bronze Age Regional Environment. Minneapolis.

Mountjoy, P.A.

1986 Mycenaean Decorated Pottery. A Guide to Identification. SIMA LXXIII. Göteborg.

1988 LH III C Late Versus Submycenaean. The Kerameikos Pompeion Cemetery Reviewed (with a Contribution by Vronwy Hankey). Jahrbuch des Deutschen Archäologischen Instituts Athen 103:1-37.

Muhly, J.D.

1984 The Role of the Sea-Peoples in Cyprus During the LC III Period. Pp. 39-55 in Cyprus at the Close of the Late Bronze Age, ed. V. Karageorghis. Nicosia.

Pilidou, D.

1994 Handmade Burnished Wares of the Late Bronze Age in Cyprus. SIMA CV. Göteborg.

Podzuweit, Chr.

1978 Ausgrabungen in Tiryns 1976: Bericht zur spätmykenischen Keramik. Archäologischer Anzeiger, pp. 471-498.

1979 Ausgrabungen in Tiryns 1977: Bericht zur spätmykenischen Keramik. Archäologischer Anzeiger, pp. 412-440.

1981 Ausgrabungen in Tiryns 1978, 1979: Bericht zur spätmykenischen Keramik. Archäologischer Anzeiger, pp. 192-220.

1983 Ausgrabungen in Tiryns 1981: Bericht zur spätmykenischen Keramik. Archäologischer Anzeiger, pp. 359-402.

1987 Zypern am Übergang von spätzyprisch II C zu III A. Pp. 185-192 in Kolloquium zur Ägäischen Vorgeschichte 1986, ed. W. Schiering. Mannheim.

1988 Keramik der Phase SH III C aus der Unterburg von Tiryns, Archäologischer Anzeiger, pp. 213-225.

Popham, M. and Milburn, E.

1971 The Late Helladic III C Pottery of Xeropolis (Lefkandi). A Summary. Annual of the British School at Athens 66:333-352.

Reber, $\mathrm{K}$.

1991 Untersuchungen zur handgemachten Keramik Griechenlands in der submykenischen, protogeometrischen und geometrischen Zeit. Jonsered.

Rutter, J.B.

1978 A Plea for the Abandonment of the term 
"Submycenaean". Pp. 58-65 in Temple University Aegean Symposion 3, ed. Ph. Betancourt. Philadelphia.

Sakellariou, M.

1990 Between Memory and Oblivion: The Transmission of Early Greek Historical Traditions. Athens.

Schachermeyr, F.

1980 Die Ägäische Frühzeit. Band IV: Griechenland im Zeitalter der Wanderungen vom Ende der mykenischen Ära bis auf die Dorier. Vienna.

1983 Die griechische Rückerinnerung im Lichte neuerer Forschungen. Vienna.

Schilardi, D.U.

1992 Paros and the Cyclades after the Fall of the Mycenaean Palaces. Pp. 621-639 in Mykenaika. Actes du IXe Colloque international sur les textes mycéniens et égéens, Athènes 1990, ed. J.P. Olivier. Athens.

Sherratt, E.S.

1981 The Pottery of LH III C and Its Signifi- cance. Unpublished Ph.D. Dissertation. University of Oxford.

Slenczka, E.

1974 Tiryns VII. Figürlich bemalte mykenische Keramik aus Tiryns. Mainz.

Spyropoulos, Th.

1972 Isteromikenaiki helladiki thesavri. Athens. Vanschoonwinkel, J.

1991 L'Égée et la Méditerranée Orientale à la fin du deuxième millénaire. Témoinages archéologiques et sources écrites. Archaeologia Transatlantica IX. Louvain-la-NeuveProvidence.

Wardle, K.A.

1993 Mycenaean Trade and Influence in Northern Greece. Pp. 117-141 in Wace and Blegen. Pottery as Evidence for Trade in the Aegean Bronze Age, 1939-1989. International Conference at Athens 1989, eds. C. Zerner, P. Zerner and J. Winder. Amsterdam. 